\title{
PENGARUH PENGENDALIAN INTERNAL DAN INFORMASI AKUNTANSI TERHADAP KUALITAS LAPORAN KEUANGAN PEMERINTAH PROVINSI KEPULAUAN RIAU
}

\author{
Bambang Sambodo \\ Prodi S1 Akuntansi, Sekolah Tinggi Ilmu Ekonomi (STIE) Pembangunan Tanjungpinang \\ sambodonasywa@yahoo.com \\ Yosihara Halimah Thussa'diyah \\ Prodi S1 Akuntansi, Sekolah Tinggi Ilmu Ekonomi (STIE) Pembangunan Tanjungpinang \\ yosiharahalimah@gmail.com
}

\begin{abstract}
Abstrak: Penelitian ini bertujuan untuk mengetahui pengaruh Pengendalian Internal dan Informasi Akuntansi terhadap Kualitas Laporan Keuangan Pemerintah Provinsi Kepulauan Riau secara parsial maupun secara simultan.Jenis penelitian yang digunakan dalam penelitian ini adalah penelitian deskriptif dengan pendekatan kuantitatif. Jenis data yang digunakan dalam penelitian ini terdiri dari data primer dan data sekunder. Metode pengumpulan data yang digunakan dalam penelitian ini yaitu menggunakan lembar kuesioner. Populasi dalam penelitian ini berjumlah 62 orang dan sampel yang digunakan adalah keseluruhan dari populasi. Metode penarikan sampel yang digunakan yaitu Non Probability Sampling dengan teknik Purposive Sampling, sehingga yang menjadi populasi dan sampel penelitian hanyalah pegawai bagian Keuangan dari setiap perangkat dinas Provinsi Kepulauan Riau.Hasil analisis regresi linear berganda didapati persamaan regresi yaitu $\mathrm{Y}=7,272+0,493 \mathrm{X} 1+0,617 \mathrm{X} 2+\mathrm{e}$, dengan tingkat error atau tingkat toleransi yaitu 5\%. Berdasarkan persamaan regresi tersebut, diketahui bahwa seluruh variabel bebas memiliki hubungan yang positif terhadap variabel bebas.Kesimpulan dari penelitian ini yaitu variabel Pengendalian Internal dan Informasi Akuntansi secara parsial maupun simultan berpengaruh terhadap Kualitas Laporan Keuangan. Dengan nilaiR Square adalah 0,719 atau 71,9\% yang artinya, variabel Kualitas Laporan Keuangan dipengaruhi oleh variabel Pengendalian Internal dan Informasi Akuntansi sebesar 71,9\%. Sedangkan sisanya 28,1\% dipengaruhi oleh variabel lain di luar penelitian ini.
\end{abstract}

Kata Kunci : Pengendalian Internal, Informasi Akuntansi, Kualitas Laporan Keuangan.

Abstract: This study aims to determine the effect of Internal Control and Accounting Information on the Quality of Financial Statements of the Riau Islands Provincial Government partially or simultaneously. The type of research used in this study is descriptive research with a quantitative approach. The type of data used in this study consists of primary data and secondary data. Data collection methods used in this study were using questionnaire sheets. The population in this study amounted to 62 people and the sample used was the entire population. The sampling method used is Non Probability Sampling with a Purposive Sampling technique, so that the only population and sample of the study is the Finance Department employee from each official service of the Riau Islands Province.The results of multiple linear regression analysis found a regression equation that is $Y=7.272+0.493 X 1+0.617 X 2+e$, with an error rate or tolerance level of 5\%. Based on the regression equation, it is known that all independent variables have a positive relationship to the independent variable.The conclusion of this study is that the Internal Control and Accounting Information variables partially or simultaneously influence the Quality of Financial Statements. With the value of $R$ Square is 0.719 or $71.9 \%$, which means, the Financial Report Quality variable is influenced by the Internal Control and Accounting Information variables of $71.9 \%$. While the remaining $28.1 \%$ is influenced by other variables outside of this study.

Keywords : Internal Control, Accounting Information, Quality of Financial Statements. 


\section{PENDAHULUAN}

Menurut peraturan pemerintah nomor 101 tahun 2000 pemerintahan yang baik merupakan pemerintahan yang mengembangkan dan menerapkan prinsipprinsip yang terdiri atas profesionalitas, akuntanbilitas, transparansi, demokrasi, efisiensi, efektivitas dan diterima oleh seluruh rakyat. Pemerintahan yang baik atau yang sering disebut good government dapat tercermin dalam proses pengelolaan keuangan, penyajian laporan keuangan, serta akuntanbilitas keuangan pemerintah. Beberapa upaya yang telah dilakukan dalam rangka mewujudkan good government maka telah dikeluarkan paket undang-undang pengelolaan keuangan negara yang meliputi; UU Nomor 17 Tahun 2003 Tentang keuangan Negara, UU Nomor 1 Tahun 2004 Tentang Perbendaharaan Negara dan UU Nomor 15 Tahun 2004 Tentang Pemeriksaan Pengelolaan dan Tanggungjawab Keuangan Negara. Ketiga paket Undang-undang ini merupakan produk legislasi sebagai wujud dan kehendak untuk melaksanakan reformasi dibidang keuangan negara sekaligus menuntut suatu perubahan mendasar dibidang pengelolaan dan pertanggungjawaban keuangan negara.

Pemerintah daerah merupakan organisasi sektor publik yang mendapatkan kewenangan luas dan nyata dari pemerintah pusat untuk bertanggungjawab dalam mengatur pemerintahannya secara mandiri. Kewenangan tersebut secara jelas diatur dalam Undang-Undang (UU) No. 22 Tahun 1999 tentang Pemerintah Daerah yang kemudian disempurnakan kembali dalam UU No. 32 Tahun 2004. Kewenangan ini pada dasarnya merupakan upaya untuk membatasi kewenangan pemerintah pusat dan kewenangan provinsi sebagai daerah otonom, dimana kewenangan tersebut memberikan peluang kepada daerah agar leluasa mengatur dan melaksanakan kewenangannya sesuai kepentingan masyarakat setempat dan potensi setiap daerah.

Laporan keuangan merupakan hasil akhir dari proses akuntansi yang memberikan suatu gambaran mengenai keadaan posisi keuangan, hasil usaha, serta perubahan posisi keuangan dalam suatu instansi pemerintah. Tidak terlepas dari peranannya laporan keuangan berguna dalam proses pengukuran dan penilaian kinerja suatu intansi pemerintah. Dalam mempublikasikan laporan keuangan sebagai informasi akuntansi yang dihasilkan instansi pemerintah, tidak terlepas dari proses penyusunannya. Laporan keuangan merupakan salah satu sumber informasi yang secara formal wajib dipublikasikan sebagai sarana pertanggung jawaban.

Bentuk laporan pertanggungjawaban atas pengelolaan keuangan daerah selama satu tahun anggaran adalah dalam bentuk Laporan Keuangan Pemerintah Daerah (LKPD). Laporan keuangan pemerintah daerah harus mengikuti Standar Akuntansi Pemerintahan sesuai Peraturan Pemerintah No.24 Tahun 2005. Tujuan diberlakukannya hal tersebut adalah agar lebih accountable dan semakin diperlukannya peningkatan kualitas laporan keuangan. Kualitas laporan keuangan pemerintah sangat dipengaruhi oleh faktor kepatuhan terhadap standar akuntansi, kapabilitas sumber daya manusia, serta dukungan teknologi, juga pengendalian internal, serta data yang akurat. Dari hasil audit Badan Pemeriksa Keuangan (BPK) memberikan opini tidak memenuhi syarat atau memenuhi syarat dalam persentase yang lebih besar atas Laporan Keuangan Pemerintah Daerah (LKPD).

Pengendalian internal merupakan bagian yang sangat penting agar tujuan perusahaan dapat tercapai tanpa adanya pengendalian internal tujuan perusahaan tidak dapat dicapai secara efektif dan efisien. Semakin besar perusahaan semakin penting pula arti dari pengendalian internal dalam perusahaan tersebut. Pada umumnya perusahaan menggunakan pengendalian internal untuk mencegah terjadinya penyalahgunaan sistem dan membantu operasional perusahaan agar dapat terarah dengan baik.

Informasi akuntansi merupakan data yang diproses dan diolah dalam bentuk pencatatan yang runtun terkait dengan keuangan ataupun transaksi sehingga dapat 
digunakan oleh pihak yang membutuhkan seperti perusahaan, lembaga, pengusaha dan lain-lain. Adanya informasi akuntansi dibuat untuk mencapai beberapa tujuan diantaranya adalah menyediakan data terkait pengelolaan keuangan dan ketepatan penyajian.

Kualitas laporan keuangan merupakan hasil ringkasan laporan keuangan yang dapat memberikan sebuah informasi keuangan yang bisa memberikan gambaran yang lebih baik mengenai prospek dan risiko perusahaan dan sesuai dengan standar yang telah ditetapkan. Laporan keuangan yang dikatakan berkualitas apabila informasi yang disajikan didalam laporan keuangan dapat dipahami, bebas dari pengertian yang menyesatkan, menyajikan fakta secara jujur serta dapat mendukung pengambilan keputusan oleh para pemakai. Serta dapat diandalkan, sehingga laporan keuangan tersebut dapat di bandingkan dengan periode sebelumnya.

Dalam laporan keuangan penyusunan laporan keuangan diperlukan guna memberikan informasi yang relevan mengenai posisi keuangan suatu entitas pada suatu periode akuntansi, sehingga laporan keuangan menjadi suatu alat yang sangat berguna untuk membantu perusahaan dalam proses pengambilan keputusan. Di sektor pemerintahan, penyusunan laporan keuangan merupakan suatu kewajiban yang harus dilakukan pemerintah untuk mempertanggung jawabkan aktivitas keuangannya kepada publik/masyarakat, sehingga kandungan informasi dalam laporan keuangan pemerintah harus benarbenar berkualitas. Kriteria dan unsur-unsur pembentuk kualitas informasi laporan keuangan disebutkan dalam Kerangka Konseptual Akuntansi Pemerintahan (PP No. 71 tahun 2010) terdiri dari: (a) relevan, (b) andal, (c) dapat dibandingkan dan (d) dapat dipahami.

Pada pemerintah daerah pengendalian internal sangat dibutuhkan agar tujuan pemerintahan dapat terlaksana dengan baik. Karena pengendalian internal terdapat indikator-indikator agar tujuan instansi pemerintah dapat tercapai. Pada pemerintah Provinsi Kepulauan Riau pengendalian internal yang diterapkan sudah cukup baik tapi belum menghasilkan hasil yang efektif dan efisien. Dikarenakan adanya keterlambatan dalam penyelesaian tugas yang dibebankan.

Pengendalian internal juga mempengaruhi informasi akuntansi yang merupakan suatu hal yang sangat penting bagi setiap instansi pemerintah sehingga untuk menunjang informasi akuntansi maka pemerintah diberi kemudahan dengan adanya SIMDA. SIMDA ini merupakan sistem yang dapat mempermudah pemerintah dalam membuat serta menyediakan laporan keuangan. Akan tetapi dalam pengaplikasian sistem tersebut masih terdapat kendala yaitu bendahara dan operator SIMDA dikerjakan oleh satu orang sehingga terdapat kesalahan pada pengiputan data. Permasalahan juga terdapat pada laporan keuangan yang tidak tepat waktu serta masih banyak ditemukan ketidaksesuaian dan beberapa kesalahan dalam pembuatan laporan keuangan.

Berdasarkan latar belakang diatas maka peneliti tertarik untuk meneliti tentang fenomena yang terjadi dalam sebuah jurnal yang berjudul "PENGARUH PENGENDALIAN INTERNAL DAN INFORMASI AKUNTANSI TERHADAP KUALITAS LAPORAN KEUANGAN PEMERINTAH PROVINSI KEPULAUAN RIAU"

Berdasarkan latar belakang diatas, maka penulis dapat membuat suatu perumusan masalah yaitu :

1. Apakah Pengendalian Internal berpengaruh terhadap kualitas laporan keuangan Pemerintah?

2. Apakah Informasi Akuntansi berpengaruh terhadap kualitas laporan keuangan Pemerintah?

3. Apakah Pengendalian Internal dan Informasi Akuntansi berpengaruh terhadap kualitas laporan keuangan Pemerintah?

\section{TINJAUAN PUSTAKA}

Pengendalian internal merupakan bagian yang sangat penting agar tujuan perusahaan dapat tercapai tanpa adanya pengendalian internal tujuan perusahaan tidak dapat dicapai secara efektif dan efisien. Semakin besar perusahaan semakin penting 
pula arti dari pengendalian internal dalam perusahaan tersebut.

Menurut (Chung, 2015) pada umumnya perusahaan menggunakan sistem pengendalian internal untuk mencegah terjadinya penyalahgunaan sistem dan membantu operasional perusahaan agar dapat terarah dengan baik.

Adapun tujuan dibangunnya sistem pengendalian internal adalah :

1) Untuk melindungi aset negara.

2) Untuk memelihara catatan secara rinci dan akurat.

3) Untuk menghasilkan informasi keuangan yang akurat, relevan, dan andal.

4) Untuk menjamin laporan bahwa laporan keuangan disusun sesuai dengan standar akuntansi yang berlaku.

5) Untuk efisiensi dan efektivitas operasi.

6) Untuk menjamin ditaatinya kebijakan manajemen dan peraturan perundang-undangan yang berlaku

Tujuan pengendalian internal itu pada dasarnya adalah untuk mencapai tujuan yang telah ditetapkan oleh perusahaan sebagaimana telah ditetapkan sebelumnya, dalam arti dapat mencapai tujuan dengan efektif dan efisien.

Sistem Informasi Akuntansi dapat diselenggarakan sepenuhnya dengan memanfaatkan teknologi komputer dan teknologi terbaru, atau dapat berupa informasi keduanya. Menurut (Wing Wahyu, 2006) mendefinisikan Sistem Informasi Akuntansi adalah sekumpulan seperangkat sistem yang berfungsi untuk mencatat data transaksi, mengolah data, dan menyajikan informasi akuntansi kepada pihak internal (manajemen perusahaan) dan pihak eksternal (pembeli, pemerintah, kreditur, dan sebagainya). (Krisimiaji, 2010) mengemukakan bahwa sistem informasi akuntansi adalah sebuah sistem yang akan memproses suatu data dan transaksi guna menghasilkan informasi yang bermanfaat untuk merencanakan, mengendalikan, dan mengoperasikan bisnis. Sedangkan menurut (Diana, 2011) definisi dari sistem informasi adalah sistem yang bertujuan untuk mengumpulkan dan memproses data serta melaporkan informasi yang berkaitan dengan transaksi keuangan. Memproses transaksi yang dimaksud bisa berupa mencatat aktivitas pengeluaran kas ke dalam jurnal. Sistem Informasi Akuntansi juga didefinisikan oleh (Bodnar, 2010) ialah sistem berbasis komputer yang dirancang untuk mentransformasi data akuntansi menjadi informasi.

Sistem Informasi Manajemen Daerah merupakan sebuah sistem pengelolaan keuangan daerah berbasis teknologi informasi yang dapat membantu pemerintah daerah dalam menghasilkan informasi keuangan yang relevan, cepat, akurat, lengkap dan dapat diuji kebenarannya. Aplikasi SIMDA juga dapat menghasilkan laporan keuangan dan informasi keuangannya lainnya secara lebih komprehensif yang meliputi informasi mengenai posisi keuangan daerah, kondisi kinerja keuangan dan akuntabilitas pemerintah daerah.

Kualitas laporan keuangan adalah hasil akhir dari proses kegiatan akuntansi atau suatu ringkasan dari transaksi keuangan. Laporan keuangandisusun untuk memberikan informasi tentang posisi harta, uang dan modal yang terjadi dalam instansi pemerintah atau suatu perusahaan serta laba dan ruginya.

\section{METODOLOGI PENELITIAN}

Jenis penelitian ini yaitu deskriptif kuantitatif. Pengertian penelitian deskriptif menurut (Sugiyono, 2011) adalah penelitian yang dilakukan untuk mengetahui nilai variabel mandiri, baik satu variabel atau lebih (independen) tanpa membuat perbandingan atau menghubungkan dengan variabel yang lain.

Menurut (Martono, 2014) data primer merupakan data yang diperoleh dari sumber pertama, atau dengan kata lain data yang pengumpulannya dilakukan sendiri oleh peneliti secara langsung seperti hasil wawancara dan hasil pengisian angket (Kuesioner). 
Sampel yang diambil dalam penelitian ini ialah Pejabat Penatausahaan Keuangan (PPK), dan Bendaharapada tiap OPD di Provinsi Kepulauan Riau. Penentuan responden dengan jumlah 62 untuk 31 OPD. Penentuan kriteria sampel didasarkan pada alasan bahwa bagian keuangan dan bagian penatausahaan keuangan merupakan pihakpihak yang sering berkaitan dengan keuangan.

\section{HASIL PENELITIAN}

Provinsi Kepulauan Riau merupakan provinsi yang penuh dengan limpahan rahmat dari Tuhan Yang Maha Esa. Selain letak geografisnya yang sangat strategis karena berada pada pintu masuk Selat Malaka dari sebelah Timur juga berbatasan dengan pusat bisnis dan keuangan di Asia Pasifik yakni Singapura. Disamping itu Provinsi ini juga berbatasan langsung dengan Malaysia.

Visi pembangunan jangka menengah daerah merupakan visi Kepala Daerah dan Wakil Kepala Daerah terpilih yang menggambarkan arah pembangunan atau kondisi masa depan daerah yang ingin dicapai (desired future) dalam masa jabatan selama 5 tahun sesuai misi yang diemban. Visi Provinsi Kepulauan Riau periode 20162021 adalah: "Terwujudnya Kepulauan Riau sebagai Bunda Tanah Melayu yang Sejahtera, Berakhlak Mulia, Ramah Lingkungan, dan Unggul di Bidang Maritim".

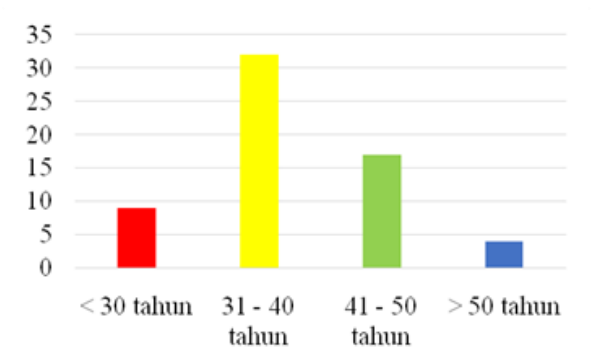

Dari diagramdiatas menunjukan karakteristik responden berdasarkan usia / umur. Namun untuk lebih jelasnya tingkat frekuensi responden bisa dilihat berdasarkan tabel.Dapat kita lihat dari tabel diatas menunjukan bahwa dari 62 responden yang dijadikan sampel memperlihatkan bahwa terdapat 9 responden yang berusia / berumur dibawah 30 tahun atau sekitar 15\%, lalu terdapat 32 reponden yang berusia / berumur 31 tahun - 40 tahun atau sekitar 52\%. Kemudian, terdapat lagi sebanyak 17 responden yang berusia / berumur 41 tahun 50 tahun atau sekitar $27 \%$, dan yang terakhir terdapat 4 responden yang berusia / berumur lebih dari 50 tahun atau sekitar 6\%. Oleh sebab itu, dapat kita simpulkan bahwa mayoritas responden pada penelitian ini yaitu berusia 31 tahun -40 tahun.

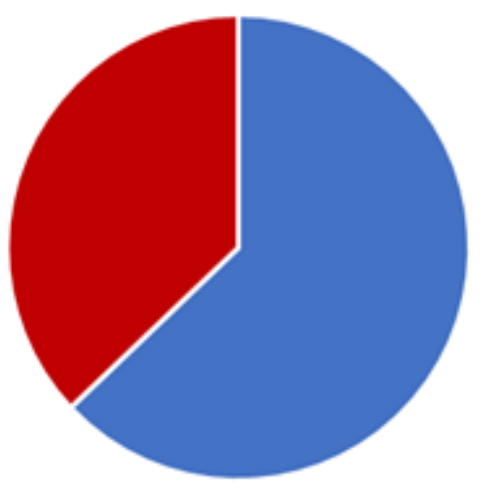

\section{- Laki-laki " perempuan}

Dari diagram diatas menunjukan karakteristik responden berdasarkan jenis kelamin, tingkat frekuensi responden bisa dilihat berdasarkan tabel 4.3 diatas menunjukkan bahwa responden terbanyak adalah berjenis kelamin laki-laki yaitu sebanyak 39 orang atau 63\%dan sisanya adalah responden berjenis kelamin perempuan yaitu sebanyak 23 orang atau $37 \%$.

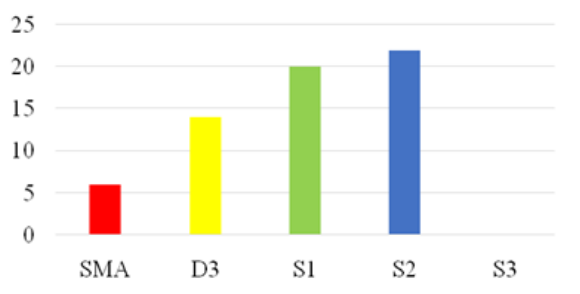

$\begin{array}{ccc}\text { Dari } & \text { gambar diatas menunjukan } \\ \text { karakteristik } & \text { responden } & \text { berdasarkan }\end{array}$ pendidikan terakhir, namun untuk lebih jelasnya tingkat frekuensi responden bisa dilihat berdasarkan tabel 4.4 diatas menunjukkan bahwa dari 62 responden yang dijadikan sampel menunjukan bahwa responden dengan jenjang pendidikan SMA berjumlah 6 orang atau $10 \%$, jenjang pendidikan D3 berjumlah 14 orang atau 23\% jenjang pendidikan S1 berjumlah 20 orang atau $32 \%$, jenjang pendidikan S2 berjumlah 
22 orang atau $35 \%$, dan jenjang pendidikan S3 tidak ada data.

Tabel Uji Reliabilitas

\begin{tabular}{|l|c|c|c|}
\hline $\begin{array}{c}\text { Variab } \\
\text { el }\end{array}$ & $\begin{array}{c}\text { Cronbanch } \\
\text { 's Alpha }\end{array}$ & $\begin{array}{c}\text { Alpha } \\
\text { Hitun } \\
\text { g }\end{array}$ & $\begin{array}{c}\text { Kesimpul } \\
\text { an }\end{array}$ \\
\hline $\mathrm{X} 1$ & 0,777 & 0,6 & Reliabel \\
\hline $\mathrm{X} 2$ & 0,805 & 0,6 & Reliabel \\
\hline $\mathrm{Y}$ & 0,774 & 0,6 & Reliabel \\
\hline \multicolumn{4}{|c|}{ Berdasarkan hasil uji reliabilitas }
\end{tabular}
seperti pada tabel diatas,Hasil Pengujian Reliabilitas menunjukkan bahwa koefisien alpha variabel Pengendalian Internal(Variabel X1) sebesar 0,777> 0,6; koefisien alpha variabel Informasi Akuntansi (Variabel X2) sebesar 0,805> 0,6; dan koefisien alpha variabel Kualitas Laporan Keuangan (Variabel Y) sebesar 0,774> 0,6. Sehingga dapat dikatakan semua konsep pengukuran hasil-hasil dari ketiga variabel pada kuesioner adalah reliabel.

\section{Hasil Uji Normalitas}

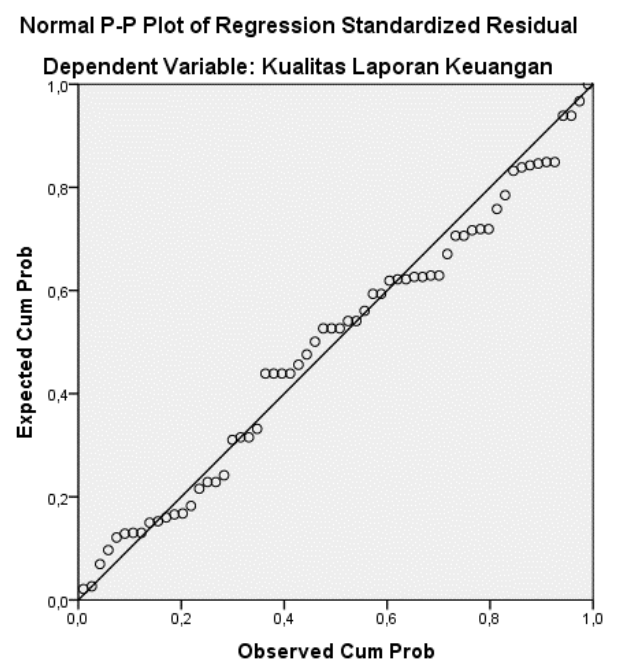

Menurut (Priyatno, 2013) dasar pengambilan keputusan adalah apabila data menyebar di sekitar garis diagonal dan mengikuti arah garis (dari sumbu 0 ke x 1.0 dan y 1.0), maka model regresi memenuhi asumsi normalitas-normalitas. Jika data menyebar jauh dari diagonal atau tidak mengikuti arah garis diagonal, maka model regresi tidak memenuhi asumsi normalitas.

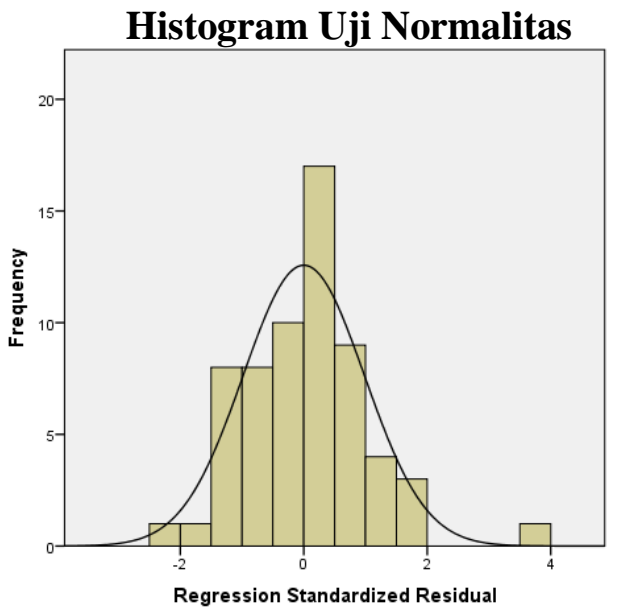

Berdasarkan gambar diatas, diketahui bahwa Hasil Uji Normalitas Data Kuesioner menunjukan bahwa persebaran data terjadi pada garis diagonal pada kurva Normal P-Plot dan membentuk sebuah lonceng pada diagram Histogram pada gambar 4.6 yang artinya Data tersebut terdistribusi Normal dan dapat dilakukan pengujian selanjutnya.

\section{Hasil Analisis Regresi Linear}

Analisis Regresi Linear Berganda digunakan untuk mengukur kekuatan hubungan antaradua variabel atau lebih, juga menunjukan arah hubungan antar variabel dependen dengan variabel independen (Priyatno, 2014).

\section{Coefficients $^{\mathrm{a}}$}

\begin{tabular}{|l|r|r|}
\hline \multirow{2}{*}{ Model } & \multicolumn{2}{|c|}{$\begin{array}{l}\text { Unstandardize } \\
\text { d Coefficients }\end{array}$} \\
\cline { 2 - 3 } & \multicolumn{1}{c|}{$\mathrm{B}$} & \multicolumn{1}{c|}{$\begin{array}{c}\text { Std. } \\
\text { Error }\end{array}$} \\
\hline 1 (Constant) & 7.27 & 2.695 \\
2 & \\
Pengendalian_Intern & .493 & .102 \\
al & .617 & .103 \\
Informasi_Akuntansi
\end{tabular}

a. Dependent Variable:

Kualitas_Laporan_Keuangan

Dari tabel diatas dapat disusun persamaan regresi linear berganda sebagai berkut :

$Y=7,272+0,493 X_{1}+0,617 X_{2}+e$

Dimana :

Y : Kualitas Laporan Keuangan 
X1 : Pengendalian Internal

X2 : Informasi Akuntansi

e :Variabel pengganggu atau error

Persamaan regresi tersebut dapat dijelaskan seperti yang dijelaskan di bawah ini :

1. Nilai konstanta sebesar 7,272 artinya jika variabel Pengendalian Internal (X1), dan Informasi Akuntansi (X2) di anggap nol maka variabel $\mathrm{Y}$ Kualitas Laporan Keuangan adalah sebesar 7,272.

2. Koefisien regresi variabel Pengendalian Internal sebesar 0,493 artinya jika Pengendalian Internal mengalami kenaikan satu satuan dengan asumsi variabel lain tetap maka Kualitas Laporan Keuangan akan mengalami peningkatan sebesar 0,493 .

3. Koefisien regresi variabel Informasi Akuntansi sebesar 0,617 artinya jika Informasi Akuntansi mengalami kenaikan satu satuan dengan asumsi variabel lain tetap maka Kualitas Laporan Keuangan akan mengalami peningkatan sebesar 0,617.

\section{PENUTUP}

Penelitian ini bertujuan untuk menganalisis pengaruh Pengendalian Internal dan Informasi Akuntansi baik secara parsial maupun secara simultan apakah berpengaruh signifikan terhadap Kualitas Laporan Keuangan atau tidak. Berdasarkan hasil analisis dan pembahasan pada penelitian ini, maka dapat disimpulkan beberapa hal sebagai berikut:

1. Dalam penelitian ini, hasil pengujian menunjukan bahwa variabel Pengendalian Internal berpengaruh signifikan terhadap Kualitas Laporan Keuangan. Hal ini ditunjukan dengan nilai $t_{\text {hitung }}$ sebesar 4,839 yang mana lebih besar dari pada $t_{\text {tabel }}$ $(4,839>2,001)$ dengan signifikansi yang lebih kecil dari 0,05 yaitu $(0,000<0,05)$ yang artinya terdapat pengaruh yang signifikan antara Pengendalian Internal terhadap Kualitas Laporan Keuangan, atau H1diterima.
2. Dalam penelitian ini, hasil pengujian menunjukan bahwa variabel Informasi Akuntansiberpengaruh signifikan terhadap Kualitas Laporan Keuangan. Hal ini ditunjukan dengan nilai $t_{\text {hitung }}$ sebesar 3,989 yang mana lebih besar dari pada $t_{\text {tabel }}$ $(3,989>2,001)$ dengan signifikansi yang lebih kecil dari 0,05 yaitu $(0,000<0,05)$ yang artinya terdapat pengaruh yang signifikan antara Informasi Akuntansi terhadap Kualitas Laporan Keuangan, atau H2 diterima.

3. Dalam penelitian ini, hasil pengujian menunjukkan bahwa variabelPengendalian Internal dan Informasi Akuntansi secara bersamasama (simultan) berpengaruh terhadap Kualitas Laporan Keuangan. Hal ini ditunjukkan dengan nilai uji $\mathrm{F}$ dihitung 75,302 sedangkan $F$ tabel sebesar 3,15 ( $74,302>3,15$ ) maka dapat disimpulkan bahwa H3 diterima yaituvariabel Pengendalian Internal dan Informasi Akuntansi secara bersama-sama (simultan) berpengaruh terhadap Kualitas Laporan Keuangan dengan nilai $R$ Square adalah 0,719 atau $71,9 \%$ yang artinya, variabel Kualitas Laporan Keuangan dipengaruhi oleh variabel Pengendalian Internal dan Informasi Akuntansi sebesar $71,9 \%$.Sedangkan sisanya $28,1 \%$ dipengaruhi oleh variabel lain di luar penelitian ini.

\section{DAFTAR PUSTAKA}

Arens, A. A. (2008). Auditing dan Jasa Assurance. Jakarta: Erlangga.

Ghozali, I. (2013). Aplikasi Analisis Multivariate Dengan Program SPSS. Semarang: Universitas Diponegoro.

Hall, J. A. (2009). Sistem Informasi Akuntansi buku 1 edisi 4. Jakarta: Salemba Empat.

Hasan, I. (2010). Analisis Data Penelitian Dengan Statistik. Jakarta: Bumi Aksara. 
Hery. (2012). Akuntansi dan Rahasia Dibaliknya. Jakarta: Bumi Aksara.

Krismiaji. (2010). Sistem Informasi Akuntansi edisi ketiga. Yogyakarta: Unit Penerbit dan Percetakan Sekolah Tinggi Ilmu YKPN.

Levany. (2011). Sistem pengendalian Internal.

Mulyadi. (2010). Sistem Akuntansi, Edisi ke3. Jakarta: Salemba Empat.

Obaidat, \& Hapsari. (2008). Accounting Information Qualitative Characteristic. Surabaya.

Priyanto, D. (2012). Belajar Cepat Analisis Data dengan SPSS. Jakarta: ANDI.

Priyatno, D. (2010). Teknik Mudah dan Cepat Melakukan Analisis Data Penelitian dengan SPSS dan Tanya Jawab Ujian Pendadaran. Yogyakarta: Gaya Media.

Rianse, U., \& Abdi. (2008). Metodologi Penelitian Sosial dan Ekonomi. Bandung: Alfabeta.

Rochaety, E. (2008). Sistem Informasi Manajemen Pendidikan. Jakarta: Bumi Aksara.

Saidin2009Audit

Committe
Siswanto, H. (2011). Pengantar Manajemen. Jakarta: Bumi Aksara.

Sugiyono. (Metodologi Penelitian Kuantitatif, Kualitatif dan R\&D). 2009. Bandung: Alfabeta.

Sugiyono. (2011). Metodologi Penelitian. Bandung: Alfabeta.

Suharyadi, \& Purwanto. (2009). Statistika Untuk Ekonomi dan Keuangan Modern. Jakarta: Salemba Empat.

Sukirman, D. (2009). Pemahaman Laporan Keuangan dengan SIMDA Keuangzn. Jakarta.

Sunyoto, D. (2014). Auditing (Pemeriksaan Akuntansi). Yogyakarta: CAPS.

Sunyoto, D. (2011). Praktik SPSS untuk Kasus. Yogyakarta: Nuha Medika.

Tunggal, A. W. (2010). Teori dan Praktek Auditing. Jakarta: Harvarindo..

Zakiyudin, A. (2011). Sistem Informasi Manajemen. Jakarta: Mitra Wacana Media.

\section{CharacteristicBandung}

